Wojciech ZIELIŃSKI

Uniwersytet Gdański

\title{
Krytyczny pluralizm w mediach, czyli kilka uwag o kapitale idei
}

\begin{abstract}
Wstęp
Czy środki masowego przekazu mogą sprzyjać porozumieniu społecznemu, neutralizowaniu społecznych konfliktów? Czy media winny być stroną w sporze o politykę? Czy polityczna wolność mediów zwalnia je z obowiązku krytycznej selekcji przekazywanych treści? Jak określać dziś moralną odpowiedzialność ludzi mediów i ich udział w kształtowaniu kultury? Uwagi zapisane poniżej nie stanowią prostej odpowiedzi na te pytania. Mogą jednak przyczynić się do tego - i z taką intencją je poczyniono - że możliwa odpowiedź będzie pełniejsza.
\end{abstract}

Spojrzenie na media realizowane jest poniżej z perspektywy krytycznego racjonalisty, analizującego sprawy społeczne przez pryzmat związków problemowych dwóch dyscyplin: socjologii (teoretycznej) i (meta)etyki. Autorzy szczególnie ważni dla niżej podpisanego to: z jednej strony, Karl R. Popper jako promotor postawy intelektualnej (i moralnej) określanej mianem krytycznego racjonalizmu, a zarazem, jako teoretyk społeczeństwa otwartego; zaś z drugiej strony, Jürgen Habermas jako wnikliwy analityk społeczeństwa współczesnego, a zarazem teoretyk działania zwanego komunikacyjnym. Deklaracja ta sugeruje - i jest tak w istocie - że ogląd niniejszy dotyczy jedynie pewnych sytuacji problemowych związanych z funkcjonowaniem mediów - generowanych przez splot działań podejmowanych na poziomie społecznej praxis, ale ujmowanych tu pojęciowo na poziomie analizy teoretycznej. $Z$ tego też względu tekst poniższy nie może aspirować do roli nośnika bezpośrednich rozwiązań problemów związanych z funkcjonowaniem wolnych mediów między kapitałem a powinnościq obywatelska, może jednak - a jeśli tak będzie, to spełni swoją rolę - stanowić źródło inspiracji ukierunkowujących problemów tych rozwiązywanie.

Rozważenie tytułowego zagadnienia rozłożono tu na trzy etapy. W pierwszym z problematyką mediów powiązano, przywołane za Habermasem, 
pojęcie działania komunikacyjnego, będącego nie jakimś akcydentalnym jedynie elementem społecznej praxis, lecz kluczowym narzędziem możliwego kształtowania jej pożądanych jakości w społeczeństwie współczesnym. W części drugiej zwrócono uwagę na problemową nietożsamość wielości jako stanu rzeczy i pluralizmu jako idei organizującej wielości tej użytkowanie - zestawiając, za Popperem, radykalnie pluralistyczną zasade dowolności doboru treści z ideą pluralizmu krytycznego. Wreszcie w ostatniej, trzeciej części analizy skupiono się na kapitale idei, jako swoistym rezerwuarze wartości wyższych, mogących organizować także codzienną praktykę mediów, o ile tylko ludzie mediów zechcą z tego kapitału korzystać; co, w dobie pop-kulturowej presji na polityczną lekkostrawność i ekonomiczną efektywność medialnego produktu, wcale nie wydaje się proste.

Motywem wiodącym niniejszej analizy jest kluczowe dla filozofii praktycznej pytanie: Jak postępować? Sugeruje ono oczywiście normatywny kształt odpowiedzi. To jednak pod znakiem zapytania stawia zarówno prostą akceptację treści możliwych odpowiedzi jak i, tym bardziej, wolę zobowiązania się do ich realizacji. Wszak uznanie ważności określonych imperatywów - niejako z definicji dotyczących tego, co dopiero stać się powinno - nie jest tym samym, co afirmacja twierdzeń naukowych opisujących stany rzeczy już istniejące.

\section{Działanie komunikacyjne}

Wydaje się, iż pojęcie działania komunikacyjnego jest dla analizy problematyki mediów nieobojętne. I to nie tylko dlatego, że środki masowego przekazu działają niejako z definicji coś komuś komunikując, ale dlatego, że komunikując, mogą one w społeczeństwie czynić porozumienie. Możliwość taka wydaje się niebagatelna dla społecznej praxis, zważywszy na atomizację współczesnego społeczeństwa, rysującą się mimo wysokiego stopnia jego nasycenia technicznymi środkami łączności. Wysoki poziom wymiany interakcji typu face to face na interakcje ,zapośredniczone przez media" bowiem m.in. przeniesienie na media większej niż dotąd dozy odpowiedzialności za ich wpływ na życie społeczne. Konstatacja ta jest jednak trafna o tyle tylko, o ile zgodzimy się socjologicznie pojętą możliwość wy-

1 Por. K. Stasiuk, Krytyka kultury jako krytyka komunikacji. Pomiędzy działaniem komunikacyjnym, dyskursem a kultura masowa, Wrocław 2003, s. 9. 
wierania wpływu powiązać z etycznie pojętą odpowiedzialnością za jego faktyczne wywieranie. Biorąc zaś pod uwagę, iż pomiędzy jednym a drugim nie ma logicznego przejścia - powinność odpowiedzialności nie wynika logicznie z samego uznania faktu wywierania wpływu - wypada uznać, że i sama taka konstatacja pozostaje przedmiotem aksjologicznego wyboru. To zaś dodatkowo wzmacnia rysującą się niepewność co do faktycznego ujmowania roli mediów w społeczeństwie współczesnym.

Działanie komunikacyjne w pojęciu, o którym tu mowa, to właśnie proces dochodzenia do porozumienia, którego kluczowym medium pozostaje język ${ }^{2}$. W ramach danej sytuacji społecznej uczestniczą w owym procesie rozmaite strony, wysuwając roszczenia ważnościowe wobec własnych interpretacji poszczególnych składowych owej sytuacji. Wzajemna, krytyczna analiza roszczeń staje się operacyjnym zalążkiem porozumienia uczestników danego działania. Otóż można powiedzieć - znacznie upraszczając oczywiście Habermasowską wykładnię teorii działania komunikacyjnego - iż w społeczeństwie współczesnym jedną ze stron tak pojętego działania są właśnie media, tzn. prasa, radio, telewizja itp.

Podkreślenie, iż chodzi tu właśnie o tego rodzaju media jest nieprzypadkowe - ma zabezpieczyć przed istotnym nieporozumieniem. U Habermasa znajdujemy bowiem, nawiązujące m.in. do badań teoretycznych Talcotta Parsonsa, szczegółowe analizy pozbawionych znamion języka tzw. mediów sterowania, jakimi są zwłaszcza: pieniadz i władza. Te media sterowania - pisze Habermas - substytuujaj język, zastępują go w roli „mechanizmu koordynacji działań”. Zarazem prowadzą do „uniezależnienia działania społecznego od integracji zapośredniczonej przez konsens aksjologiczny (Wertkonsens) oraz do przestawienia go na sterowaną przez media racjonalność ukierunkowaną na cel". Pojawia się tym samym swoista sprzeczność - uchwytna, jak podkreśla cytowany autor, właśnie za pomocą aparatury pojęciowej teorii działania komunikacyjnego - pomiędzy „narastającą złożonością podsystemów działania racjonalnego ze względu na cel”, w ramach których działania koordynowane są właśnie za pośrednictwem wyżej wymienionych mediów sterowania, a - ,powiązaną ze strukturami intersubiektywności świata życia - racjonalizacją codziennego komunikowania się, dla którego język stanowi pierwotne i niezastępowalne medium dochodzenia do porozumienia"3.

2 Por. J. Habermas, Teoria działania komunikacyjnego, t. 1, Racjonalność dziatania a racjonalność społeczna, Warszawa 1999, s. 186, 190.

3 Por. ibidem, s. 559 i n. 
W poniższym zastosowaniu mowa oczywiście o mediach - prasie, radiu, telewizji - które nie są pozbawione znamion języka, lecz które, przeciwnie, posługują się nim jako narzędziem kluczowym. Pojawia się tu jednak ponownie istotny wątek analityczny, a mianowicie, zasadność odróżnienia roli języka ww. mediów ujmowanej na płaszczyźnie opisu od jego roli ujmowanej na płaszczyźnie wartościowania. Otóż w pierwszym przypadku rzecz dotyczy, oczywistej dla środków społecznego przekazu, technicznej roli języka jako, mówiąc najogólniej, przekaźnika informacji. Nie byłoby ww. mediów, gdyby nie istniał tak pojęty język umożliwiający ich funkcjonowanie. W przypadku drugim natomiast, lokującym się na wartościującej płaszczyźnie analizy omawianego problemu, nasza uwaga kierowana jest na język mediów jako na możliwe narzędzie koordynacji działań społecznych, którego to procesu przeciwieństwem byłoby natomiast dezintegrowanie społecznego działania, wywołane negatywnie ocenianym funkcjonowaniem mediów. Innymi słowy, nawiązując do powyższych uwag zaczerpniętych od Habermasa, chodzi tu o rozważenie możliwości konsensualnego i, co za tym idzie, integrującego oddziaływania mediów na życie społeczne, i o rozpatrzenie ewentualnych czynników takiego oddziaływania.

Oczywiście to drugie z ww. ujęć roli języka mediów - ujęcie wartościujące - nosi znamiona określonej decyzji aksjologicznej, przyznającej mediom możliwość pozytywnego oddziaływania na życie społeczne i dopuszczającej zarazem - bo jest to logicznie konsekwentne - możliwość krytycznej oceny ich wpływów negatywnych. Takie postawienie sprawy nie jest zatem samo przez się konieczne - wszak funkcjonowanie mediów można rozpatrywać konsekwentnie również wyłącznie w kategoriach opisowych - ale też nie wydaje się ono ani odosobnione, ani nieznaczące, skoro przedmiot analizy - media - budzi dziś tak wiele faktycznych kontrowersji w społecznej praxis.

Załóżmy w tym miejscu, wykorzystując wartościujące ujęcie roli języka mediów i powracając zarazem do wcześniejszego wątku, że media są stroną uczestniczącą w działaniu komunikacyjnym - w społecznym procesie budowania porozumienia. Obok nich, w ramach danego społeczeństwa, w działaniu tym uczestniczą: centralne i lokalne ośrodki władzy, instytucje ekonomiczne, naukowe, kulturalne i in. oraz tzw. zwykli ludzie, będący przedmiotem oddziaływań stron wyżej wymienionych, ale także pozostający podmiotami działania komunikacyjnego w skali sobie właściwego oddziaływania. Otóż każda z wymienionych stron - ich krótka lista ma tu oczywiście charakter wyłącznie poglądowy, służy teoretycz- 
nej analizie sytuacji problemowej mediów i w żadnym wypadku nie pretenduje do miana wyniku socjologicznej inwentaryzacji struktury społecznej - kieruje pod adresem stron pozostałych roszczenia ważnościowe dotyczące własnego opisu świata, ściślej, własnego opisu spraw społecznych, w których jakoś współuczestniczy ze stronami pozostałymi. Charakter i siła tych roszczeń oraz możliwości ich kanalizowania są oczywiście niejednakowe. Wszak trudno stawiać na jednej szali: masowy i błyskawiczny telewizyjny przekaz informacji, systemowe oddziaływanie władzy za pośrednictwem stanowienia i egzekwowania prawa i np., kierowane pod adresem najbliższego otoczenia, pretensje tzw. zwykłego człowieka związane z jego własną sytuacją materialną. Nie to jest jednak tutaj istotne. Interesują nas bowiem przede wszystkim media i kierowane przez nie na adres odbiorców roszczenia ważnościowe dotyczące owego medialnego wizerunku spraw społecznych. Pojawia się pytanie: Jaki to jest wizerunek? Czy jest on efektem bezładnej ekspozycji wielości spraw i problemów przypadkowo ze sobą zestawianych, czy może jednak zawiera pierwiastki jakiegoś sensownego ich porządkowania? Czy pozostaje efektem pracy ludzi przypadkowych, czy może jednak przejawia jakościowe aspiracje jego świadomych twórców? Sprawa ta na razie pozostaje niejasna. Jedno natomiast wydaje się pewne. Praktyczne rozstrzygnięcie wątpliwości w tych pytaniach zawartych nie zależy od mediów jako takich, ale od konkretnych ludzi, którzy media tworzą. Tymczasem dochodzimy do drugiego punktu niniejszej analizy, mianowicie, do sygnalizowanego powyżej zagadnienia wielości.

\section{Pluralizm krytyczny}

Przyjmijmy na wstępie tej części analizy, iż w świecie wolnych mediów pluralizm - najogólniej pojęta mnogość, wielość składników je tworzących - nie jest już ideą, lecz stanem rzeczy. Ideą pozostawał dopóty, dopóki media nie były politycznie wolne. Jest to oczywiście kolejne daleko idące uproszczenie. Wszak polityczna wolność nie gwarantuje np. docelowej równości ekonomicznej podmiotów społecznych, co z kolei pod znakiem zapytania stawia - żywo dziś dyskutowane - zagadnienie niezależności mediów od świata biznesu. Jednak również i to zagadnienie, podobnie jak wcześniej: systemowa niejednakowość roszczeń ważnościowych stron działania komunikacyjnego, wykraczają poza zakres niniejszej analizy. Tu interesuje nas ów stan faktyczny ujęty minimalistycznie, 
bez wnikania w zbędne dla analizy szczegóły, a zatem ujęty w sposób właściwy dla rozważania sytuacji problemowej mediów, choć zapewne niewłaściwy dla analizy szczegółowych uwarunkowań ich funkcjonowania. W owym ujęciu minimalistycznym zatem media funkcjonujące w społeczeństwie demokratycznym, politycznie wolnym, same występują w liczbie mnogiej i treści, które są przedmiotem ich przekazu również ową cechę mnogości posiadają.

Wydaje się, iż na poziomie opisu stanu rzeczy powyższe, minimalistyczne ujęcie problemu nie powinno budzić większych zastrzeżeń. Odłóżmy teraz jednak na bok zagadnienie wielości nadawców - bo i ono wykracza poza założone ramy niniejszej analizy - i zajmijmy się wyłącznie ową mnogością na poziomie treści medialnego przekazu. Szybko staje się jasne, że określony stosunek zainteresowanych stron do faktycznego, opisowo ujętego, pluralizmu treściowego mediów nie jest tym samym, co owa faktyczna wielość, a mówiąc inaczej, jest czymś, co lokuje się na innej niż owa wielość płaszczyźnie. Chodzi tu oczywiście o ponowną ekspozycję w analizie elementu wartościowania.

Dla porządku, po raz kolejny upraszczając, wyróżnijmy dwa przeciwstawne typy wartościującego odniesienia do treściowego pluralizmu mediów, określając je odpowiednio mianem: 1) pluralizmu radykalnego i 2) pluralizmu krytycznego. Stanowiska te mają swoje osadzenie literaturowe zarówno w sferze filozofii kultury, jak i w obrębie tego, co można określić mianem etycznej warstwy teorii poznania. Podkreślić przy tym należy, iż mówiąc zarówno o pluralizmie radykalnym, jak i o pluralizmie krytycznym, mamy do czynienia już nie ze stanami rzeczy, lecz z ideami odnoszącymi się do stanów rzeczy; choć, jeśli chodzi o pierwszy z wymienionych pluralizmów - radykalny - ma on swoich orędowników, jako rzekomy stan faktyczny, właściwy społeczeństwu w tzw. ponowoczesnej fazie jego rozwoju ${ }^{4}$.

Postawa pluralisty radykalnego odnoszącego się do treściowej zawartości produkcji medialnej zdaje się sugerować, iż zawartość owa jest tym lepsza, im większa jest mnogość jej składników. Pluralista radykalny uznaje niejako, że wielość rozmaitych treści rejestrowana w mediach, i szerzej, w obrębie kultury współczesnej, jest wartością samą w sobie, swoistym osiągnięciem właśnie naszych czasów, a zagrożeniem są dla

4 Por. W. Zieliński, Status etyki w kulturze ponowoczesnej. Analiza propozycji Zygmunta Baumana, Toruń 2001, s. 73-86. 
niej wszelkie próby jej wartościującego porządkowania, sugerujące możliwość jakiegoś odrestaurowania bezpowrotnie utraconej jedności $i^{5}$. Tymczasem, właśnie za sprawą niczym nieskrępowanej ekspozycji wielości, dokonywanej w znacznej mierze przez media, każdy uczestnik życia społecznego ma dziś możliwość swobodnego konstruowania zarówno obrazu świata, w którym żyje, jak i własnego sposobu na życie w nim prowadzone. Paradoksalnie, mimo niekonieczności aksjologicznego wyboru idei pluralizmu radykalnego, wydaje się, że nie ma faktycznie istotnych powodów, by kwestionować dogodność tej sytuacji po stronie odbiorców medialnego przekazu. Czy jednak to samo można powiedzieć o społecznej roli jego nadawców? Jeśli uznać, że ich praca jest ,jak każda inna”, i że ludzie mediów, podobnie jak wielu innych, pracują przede wszystkim zarobkowo, dla siebie, to nie sposób zasadnie odmawiać im możliwości dogodnego udziału w owym niezobowiązującym do niczego procesie reprodukowania mnogości. Tego typu rozstrzygnięcie jest jednak co najmniej problematyczne z punktu widzenia pluralisty krytycznego, który z definicji niejako nie stroni od wartościowania treści, z którymi ma do czynienia.

Pluralista krytyczny ${ }^{6}$ uznaje, że wielość jest stanem rzeczy - właściwym życiu społecznemu prowadzonemu w warunkach demokracji. Tak pojęta wielość nie jest dlań jednak wartością samą w sobie, lecz instrumentem umożliwiającym wykształcanie nowych jakości. To jednak może dokonywać się tylko wówczas, gdy wszelkie treści życia społecznego składniki owej wielości - poddane zostaną, a ściślej, będą permanentnie poddawane krytycznej dyskusji. W dyskusji krytycznej jest natomiast miejsce na krytyczne - a więc np. nie dogmatyczne - wartościowanie. Tak pojęta krytyczna dyskusja wszelkich treści życia społecznego, motywowana chęcią wykształcania w nim nowych jakości owo życie doskonalących, jawi się tutaj jako nic innego, jak tylko działanie komunikacyjne - proces budowania porozumienia w warunkach określonej społecznej koegzystencji. Ważną stroną tego procesu, o czym była mowa wcześniej, są właśnie media. A zatem ludzie mediów postrzegani są tutaj, przez pluralistę krytycznego, jako współtwórcy kultury życia społecznego. Uznanie tej roli zobowiązuje ich do określonych postaw, ale zobowiązanie owo nie ma charakteru arbitralnego - nie jest narzucone przez którąś z pozo-

5 Por. W. Welsch, Nasza postmodernistyczna moderna, Warszawa 1998, s. 9, 59.

6 Por. K. R. Popper, W poszukiwaniu lepszego świata, Warszawa 1997, s. 224 i n. 
stałych stron działania komunikacyjnego - lecz zdaje się stanowić immanentny, a zarazem konstytutywny składnik owego działania.

Jeśli ludzie mediów uczestniczący w działaniu komunikacyjnym są faktycznymi współtwórcami kultury, a wielość jest faktycznym stanem rzeczy właściwym dzisiejszemu życiu społecznemu, to - przynajmniej z punktu widzenia pluralisty krytycznego - swoistym marnowaniem twórczego potencjatu wydaje się być medialne promowanie wielości: obserwowana nierzadko w prasie, radiu czy telewizji promocja wielości dla samej wielości, swoiste mnożenie bytów bez potrzeby. Znacznie właściwsze wydaje się wielości tej porządkowanie; tym bardziej, że leży ono niejako w interesie współczesnego człowieka, który potrzebuje już nie tyle kolejnych zestawów informacji o świecie, ile przede wszystkim wiedzy o nim jakoś usensowionej ${ }^{7}$. Takie porządkowanie wielości dokonywane przez ludzi mediów to, w nakreślonej tu perspektywie, przede wszystkim elementarne oddzielanie informacji od komentarza, ale także - co nie jest już tak oczywiste - podawanie obok treści przekazu także kryteriów ich medialnej selekcji. Krytyczny pluralista, współuczestniczący - jako widz, słuchacz czy czytelnik prasy - w działaniu komunikacyjnym, chciałby nie tylko widzieć, słyszeć i odczytywać treści medialnego przekazu, ale także chciałby dowiadywać się, dlaczego te właśnie treści są mu oferowane. Byłaby to zatem nie tylko ekspozycja wyników pracy ludzi mediów, ale także ekspozycja idei ową pracę motywujących. Dawałaby ona odbiorcom faktycznie większą wiedzę o świecie, a przy tym - zwiększając stopień ich zaufania do mediów, wzmacniany tu znajomością kryteriów selekcji treści medialnego przekazu - służyłaby realizacji procesu działania komunikacyjnego.

Reasumując uwagi zawarte w drugiej części niniejszej analizy, podkreślmy zatem, że nie jest dziś ideą wielość jako taka, ale i w świecie wolnych mediów ideą - a zatem niekoniecznym przedmiotem aksjologicznego wyboru - pozostaje pluralizm krytyczny. Realizacja tej idei w mediach dokonuje się wówczas, gdy pozostają one rzeczywistą areną debaty publicznej - miejscem krytycznej konfrontacji rozmaitych stanowisk - powodowanej niczym innym, jak tylko chęcią przybliżenia się do prawdy o otaczającym nas świecie.

Por. T. Szkołut, Sztuka wspótczesna wobec sporów o ponowoczesność, w: Aksjologiczne wyzwania przysztości, red. T. Szkołut, „Studia Etyczne i Estetyczne”, zbiór trzeci, Lublin 1996, s. 128. 


\section{Kapital idei}

Treść poprzedniego akapitu wymaga pewnego rozwinięcia właśnie w tym miejscu, gdzie ma już być mowa o kapitale idei. Otóż nieprzypadkowo przywołano powyżej ideę prawdy. Ma ona bowiem decydujące znaczenie dla niniejszej analizy, a co za tym idzie, także dla konfrontacji pluralizmu krytycznego i przedstawionego wcześniej pluralizmu radykalnego. Ów pluralizm radykalny, jako określone stanowisko aksjologiczne zajmowane wobec wielości będącej stanem rzeczy, jest odmianą relatywizmu. Relatywizm zaś, mówiąc słowami Poppera, jest stanowiskiem, według którego „twierdzić można wszystko lub prawie wszystko, a przeto nic. Wszystko jest prawdziwe lub nic. Prawda jest więc bez znaczenia"8. Pomijając inne względy, warto zwrócić uwagę, że słowa te, właściwie bez jakiejkolwiek korekty, stanowić mogą zapis obiegowej recenzji środków społecznego przekazu. I konstatacja ta jest oczywiście ponura. Tu jednak podkreślić należy, że moralna kondycja mediów dopiero w drugim rzędzie zależy od obiektywnych warunków ich funkcjonowania, w pierwszym zaś - przede wszystkim od wyborów aksjologicznych ludzi, którzy media tworzą. Przedmiotem tych wyborów mogą być właśnie idee.

Idea prawdy pozostaje konstytutywnym składnikiem naszego europejskiego kapitału kulturowego i może nadal pełnić rolę idei regulatywnej ${ }^{9}$ na wszystkich poziomach naszej wiedzy o świecie, a zatem także na poziomie wiedzy oferowanej przez media. Jej aktywna obecność w społecznej praxis zależy jednak nie od niej samej - wszak takiej mocy żadna idea nie posiada - lecz od ludzi, którzy z niej skorzystają. W świecie mediów dotyczy to oczywiście, mówiąc najogólniej, dziennikarzy. I tu pojawia się pewien problem. Wszak ekspozycja roli idei prawdy nie stanowi tu żadnego odkrycia, a i niełatwo byłoby znaleźć kogoś, kto nie deklarowałby jej stosowania w praktyce. Niemniej jednak, warte odróżnienia jest epistemologiczne zastosowanie idei prawdy od jej możliwego zastosowania i oddziaływania moralnego. W pierwszym przypadku nie stanowi bowiem większego problemu powiązanie regulatywnej idei prawdy z określoną definicją prawdy, niekoniecznie klasyczną. Rzecz dotyczy tu bowiem jedynie jakiegoś poznawczego odniesienia podmiotu do określonego wycinka, aspektu rzeczywistości - odniesienia konsekwentnie realizowanego

8 Por. K. R. Popper, W poszukiwaniu lepszego świata, s. 225.

9 Por. tenże, Wiedza obiektywna. Ewolucyjna teoria epistemologiczna, Warszawa 2002, s. 44. 
w epistemologicznych ramach wyznaczonych przez zastosowanie określonej definicji prawdy. W przypadku drugim natomiast chodzi o owo społeczne działanie komunikacyjne, którego realizacji nie zaspokaja wyłącznie logiczna kompetencja uczestników działania i proceduralna konsekwencja prowadzonych przezeń procesów poznawczych. „Ja mogę się mylić, ty możesz mieć rację, i wspólnym wysiłkiem możemy zbliżyć się do prawdy" - to credo moralne krytycznego racjonalisty ${ }^{10}$, przełożone na język społecznej praxis, oznacza nieustanną gotowość do bezinteresownej konfrontacji własnej wiedzy o świecie z wiedzą innych uczestników społecznego działania, także w jakimś sensie mniej kompetentnych. Czy w świecie mediów tak właśnie, moralnie pojęta regulatywna idea prawdy jest dzisiaj jakoś obecna? Czy ludzie mediów mogą - o ile chcą tylko stosować to moralne credo? Pytania pozostają otwarte.

Kolejną ideą stanowiącą wyposażenie naszego kulturowego kapitału, a posadowioną przecież na regulatywnej idei prawdy, jest właśnie przywołana wcześniej idea pluralizmu krytycznego. By nie powtarzać uwag na jej temat już poczynionych dopowiedzmy tu tylko, że stanowi ona swoisty iloczyn wspomnianej idei prawdy i - nie mniej ważnej dla naszego dziedzictwa kulturowego - idei wolności. W społecznej praxis oznacza zaś niezgodę na bezkrytyczną dowolność. Jeśli zatem można mówić o czynieniu porozumienia dokonywanym również za sprawą tej idei, to jawi się ono nie jako mozaikowy efekt nieselektywnego łączenia treści rozmaitych, ale, przeciwnie, jako wynik ich wielopoziomowego konkurowania, umożliwiającego przysłowiowe oddzielanie wartościowego ziarna od bezużytecznych lub szkodliwych plew ${ }^{11}$. Czyż bowiem może i powinna istnieć absolutna wolność publikowania wszystkiego? - powtórzmy za Popperem to istotne pytanie ${ }^{12}$. Ale też, z drugiej strony, czy w dzisiejszym funkcjonowaniu mediów można odnaleźć ślady aktywnej obecności tak pojętej idei pluralizmu krytycznego? Kolejne pytania pozostają otwarte.

Jako trzecią i ostatnią z wybranych do niniejszej analizy wymieńmy ideę demokracji niedoskonatej. Będąc nośnikiem normatywnego pojęcia demokracji, przeciwstawiającego się ujmowaniu tejże li tylko w katego-

10 Por. tenże, Mit schematu pojęciowego. W obronie nauki i racjonalności, Warszawa 1997, s. 10.

11 Por. H. Albert, Europa i okiełznanie władzy. Szczególna droga Europy do spoteczeństwa otwartego, Kraków 1998, s. 45 i n.

12 Por. K. R. Popper, W poszukiwaniu lepszego świata, s. 186. 
riach instytucjonalnych ${ }^{13}$, pozostaje ona oczywiście ściśle związana z ideami przywołanymi powyżej, i, podobnie jak poprzednia, stanowi zarazem rodzaj aksjologicznej konstrukcji służącej analizie społecznej praxis. W myśl owej idei, demokracja nie jest samosterowna - sama przez się nie prowadzi ani do dobrych, ani do złych stanów spraw społecznych, ale pozostaje jedynie vehiculum - nośnikiem jakości właściwych jej gospodarzom. Stąd pytanie: Kto staje się gospodarzem demokracji na różnych jej poziomach, np. w mediach? Nie formułując dokładnej odpowiedzi, zwróćmy uwagę na rzecz następującą: Ludzi rozsądnych w polityce niepokoi możliwość objęcia władzy przez populistów, jakiejkolwiek politycznej „maści” by oni byli. Zabiegając, by tak się nie stało, ludzie rozsądni wartościuja: uznając demokratyczną wielość na poziomie stanu rzeczy, przedkładają zarazem jedne rozwiązania polityczne ponad inne, realizując tym samym zasadę pluralizmu krytycznego na poziomie idei. Wszak postępowanie takie nie narusza reguł demokratycznego ładu. Paradoksalnie podkreśla jednak, że ów ład - w znaczeniu moralnym, a nie tylko instytucjonalnym - jest stanem permanentnie przyszłym; jest owym lepszym, które pozostaje odwiecznym wrogiem teraźniejszego dobrego ${ }^{14}$. Czy jednak powyższe uwagi mają zastosowanie do analizy świata mediów? Wydaje się, że tak. Wszak idea demokracji niedoskonałej wzmacnia wcześniej dokonane uznanie, iż możliwość prezentacji rozmaitych treści nie wyklucza możliwości ich wartościowania. Co więcej, idea ta motywuje - zarówno odbiorców medialnego przekazu, jak i jego nadawców, dziennikarzy - do głośnego zapytywania nie tylko o merytoryczne, ale także o moralne kwalifikacje gospodarzy demokracji medialnej. Jeśli jednak dokonane powyżej porównanie konsekwentnie dopełnić, wypadnie nam zauważyć, że zapewne nie wszyscy - tylko ludzie rozsqdni-zechcą o to pytać. Czy ich głos będzie zaś wystarczająco donośny, by medialny ład demokratyczny nie był li tylko instytucjonalną fasadą faktycznej bylejakości medialnych produktów, wzmacnianej kolejnymi, korzystnymi wynikami sondażowych badań ich społecznej konsumpcji, dokonywanymi w myśl zasady, że o jakości danego produktu świadczy stopień zadowolenia jego masowego odbiorcy? To kolejne pytanie, na które bezpośredniej odpowiedzi w tym tekście nie będzie. I kolejna suge-

13 Por. A. M. Kaniowski, Wstęp. Rehabilitacja i transformacja filozofii praktycznej, w: J. Habermas, op. cit., s. XIII.

14 Por. W. Zieliński, Czy , lepsze” przestanie być wrogiem ,,dobrego”? Na marginesie sporu o etykę, „Studia Gdańskie” 1998, t. XI, s. 5-17. 
stia, że jakość życia społecznego na rozmaitych jego poziomach, to w decydującej mierze pochodna wyborów aksjologicznych jego świadomych twórców.

\section{Zakończenie}

Formalno-prawna gwarancja wolności mediów, przynajmniej przedstawicielowi filozofii praktycznej, nie wydaje się tożsama z uznaniem prawa do ich kulturalnej swawoli. Jeśli prawdą jest, że człowiek tworzy kulturę, a ta zwrotnie oddziałuje na niego, kształtując go niejako „na swój obraz i podobieństwo", i jeśli prawdą jest to - co czasami mówią sami dziennikarze - że coraz częściej wyznacznikiem poziomu medialnych produktów staje się widz, słuchacz czy czytelnik najgłupszy, to przynajmniej etyk ma prawo taki stan rzeczy kontestować, i ma prawo pytać ludzi mediów, czy może jednak nie warto byłoby porzucić ideologię wolności mówiąca, iż w mediach ujdzie wszystko, co nie jest prawem zabronione, byleby umiało na siebie zarobić; i czy może jednak nie warto byłoby pokusić się o powrót w mediach do pracy kulturo-twórczej na wyższym niż „podwórkowy” poziomie; i czy może nie warto byłoby zadbać o eliminację z własnego środowiska ideologów i praktyków lekkostrawnej płycizny - bez względu na to, jaki jest ich polityczny rodowód.

Powyższe, owszem, brzmi patetycznie. I zapewne ludziom mediów wyda się oderwane od codziennych realiów ich funkcjonowania. Ale de facto zdystansowany, filozoficzny ogląd rzeczywistości - zwłaszcza dokonywany z perspektywy antyspekulatywnego, krytycznego racjonalizmu - wcale nie musi być dla praktyka niestrawny. Wszak ogląd ten - i nie jest to jakieś ,,nowe odkrycie” - ujmuje stany rzeczy znane z codziennego doświadczenia i pokazuje, że regulatywne idee wyższe, mogące kształtować społeczną praxis, są w zasięgu ludzkiego umysłu, a zatem także i ręki, o ile tylko akt woli wprawi ją w określony ruch.

Posłużmy się następującym porównaniem. Oto marsz protestu przeciwko złu gromadzący tysiące ludzi, choćby taki jak ten odbyty w marcu 2004 r. w Madrycie, po krwawym zamachu terrorystycznym, jest przykładem społecznego działania. Na pierwszy rzut oka wydaje się on być podobnym do wielu innych masowych protestów znanych z historii dwudziestego wieku. Ale bliższe spojrzenie ujawnia jego odmienność: protest nie ma tu bowiem realnego adresata. Wszak zło przestało już być w naszej kulturze kojarzone z osobowym działaniem diabelskim, a terroryzm jako 
taki pozostaje abstrakcją, choć materializuje się w krwawych aktach konkretnego działania. Czyż w tej sytuacji braku jasno określonego realnego adresata jakikolwiek marsz nie wydaje się jedynie aktem społecznej, ale także intelektualnej bezsilności? Ale - ktoś zapyta niecierpliwie - co to ma wspólnego z podjętą powyżej problematyką mediów? Odpowiedź rysuje się w formie kolejnego, ostatniego już, otwartego pytania: A czyż podobną nuta bezsilności nie brzmią wszelkie próby narzekania na media i wszelkie próby reformowania mediów ujmujące ów ludzki wytwór w kategoriach abstrakcji? Wszak to konkretni ludzie - osoby - tworzą miejsca i stany rzeczy: urzędy i uniwersytety, parlament, telewizję czy rynek. I to oni - owe osoby - a nie jakieś abstrakcyjne mechanizmy, kształtują określoną jakość owych miejsc i stanów. To, czy jest to byle-jakość bezkrytycznej dowolności treści, czy też jakościowa próba ich krytycznego wartościowania, pozostaje przedmiotem ich - owych konkretnych ludzi własnych wyborów. Każdy taki wybór, ujęty w analitycznej mikroskali społecznego działania, pozostaje wyborem osobowym - wyborem, za który zawsze trzeba jakoś zapłacić.

\section{Summary}

The considerations on the subject of this paper are divided into three parts. The first one relates the problems of the media to the notion of communication activity, as understood by Hamermas, that does not merely constitute an accidental element of social praxis, but is a key instrument of potential shaping of the desirable quality of this praxis in the modern society. The second part discusses the nonidentity of the multitude as status quo and pluralism as the idea that organizes the use of this multitude. This is done by means of Popper's juxtaposition of the radically pluralistic principle of freedom in the selection of the content with the idea of critical pluralism. Finally, the third part of the analysis focuses on the capital of ideas as a certain reservoir of higher values that may also organize the everyday practice of the media, provided that the media people are willing to take advantage of this capital. This appears not to be easy given the pop-cultural pressure for political digestibility and economic efficiency of the media product. 